\title{
Contribution of mitochondrial and cytoplasmic protein synthesis to the formation of cytochrome $b$ and cytochrome $a_{3}$.
}

\author{
H. Weiss, W. Sebald, A. J. Schwab, W. Kleinow and B. Lorenz. \\ Institut für Physiologische Chemie und Physikalische Biochemie \\ der Universität München.
}

\begin{abstract}
Summary. - A cytochrome b preparation from Neurospora crassa mitochondria is found to consist of three polypeptides (apparent molecular weight 10000,11000 and 32000 ), a cytochrome $\mathrm{aa}_{3}$ preparation of six to seven polypeptides (apparent molecular weight $8000,11000,13000,18000,28000$ and 36000 ).

Selective incorporation of radioactive amino acids by either mitochondrial protein synthesis when the cytoplasmic one is blocked or by the cytoplasmic protein synthesis, when the mitochondrial one is blocked, indicates that one cytochrome $b$ polypeptide ( $m$ w 32000 ) and one to three cytochrome $a a_{3}$ polypeptides (mw 36000,28000 and 18000) are mitochondrial translation products, the other cytochrome $b$ and cytochrome $a_{3}$ polypeptides cytoplasmic translation products.

The delayed appearance of labeling in the cytochrome $b$ and cytochrome $a_{3}$ polypeptides compared to the average cell protein after a pulse of $3 \mathrm{H}$ leucine revealed that these polypeptides are derived from separate pools of precursor polypeptides. The pool sizes range from $2 \mathrm{p}$. cent to $25 \mathrm{p}$. cent of the amount of the corresponding polypeptide present in the cytochromes.

The 32000 molecular weight polypeptide of cytochrome $b$ and at least the $18000 \mathrm{molecu}-$ lar weight polypeptide of cytochrome $\mathrm{aa}_{3}$ are mitochondrial translation products as well in the fungus Neurospora crassa as in the insect Locusta migratoria. So, despite the fact that the size of mitochondrial DNA and mitochondrial ribosomes is reduced in insects, the products have maintained their characteristics.
\end{abstract}

Mutations in fungi of nuclear or of mitochondrial genes $i 1,2]$ and modifications effected by inhibitors of cytoplasmic or of mitochondrial protein synthesis $[3,4]$ may lead to a loss of the mitochondrial cytochrome $b$ and cytochrome $a_{3}$. Therefore both, cytoplasmic and mitochondrial protein synthesis have been suggested to be involved in the formation of these cytochromes.

The individual contribution of each of the two protein synthesizing systems was investigated by following the incorporation of radioactive amino acids into these cytochromes either by mitochondrial protein synthesis when blocking the cytoplasmic system or by cytoplasmic protein synthesis when blocking the mitochondrial system.

The rapidly growing fungus Neurospora crassa proved especially appropriate for these studies, because catabolism of added radioactive amino acids in this fungus can be neglected compared to incorporation [5]. Radioactive leucine added as a pulse to exponentially growing cells disappears within two minutes from the culturing medium (fig. 1). The radioactivity present in the cellular pool of free leucine increases during the first minute and decreases subsequently to a neglegible value. The total protein is rapidly labeled after a short lag of half a minute. After five minutes it contains $85 \mathrm{p}$. cent of the total radioactivity.

Cytochrome $b$ and cytochrome $\mathrm{aa}_{3}$ were prepared from the radioactivity labeled mitochondrial membranes by means of chromatography on oleyl-polymethacrylic acid resin [6]. This new technique is applicable to small scale preparations. The resin contains both, weakly acidic carboxylic groups and hydrophobic aliphatic chains (fig. 2). Mitochondrial membrane protein solubilized with weakly acidic detergents such as bile acids is bound to this resin the carboxylic and the oleyl-groups replacing the detergents. On elution with gradients of increasing detergent concentration and increasing salt concentration in the presence of detergent cytochrome $b$ and cytochrome $\mathrm{aa}_{3}$ appear in distinct fractions well separated from each other and from a number of proteins containing no cytochromes (fig. 3 ).

The final cytochrome b preparation obtained after two additional purification steps, chromatography on DEAE-cellulose and gel filtration on 
Sephadex G-200, was found to contain three polypeptides, two smaller ones with apparent molecular weights of 10000 and 11000 and a larger one of 32000 , as revealed by means of polyacryl-

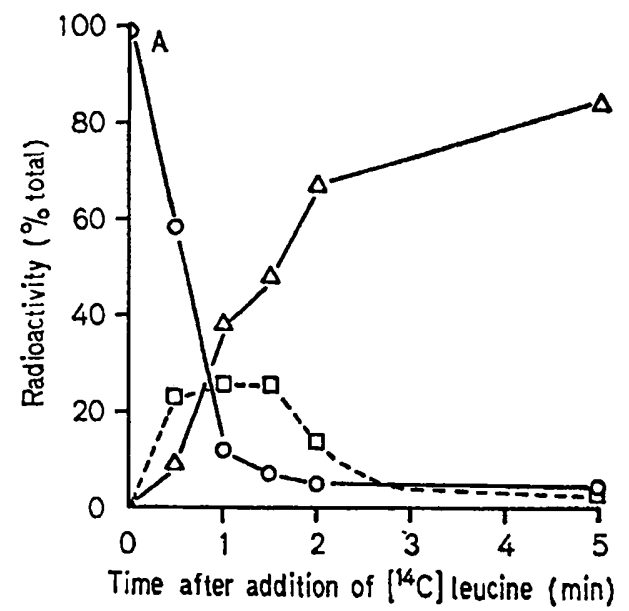

FIG. 1. - Pulse labeling of cellular proteins of Neurospora crassa by addition of (14C)-leucine to the culture medium.

Cells were incubated with $0.19 \mu \mathrm{mol}(14 \mathrm{C})$-leucine/g protein. Time-course of radioactivity in the culture medium $O-{ }^{-}$, in the cellular free leucine pool radioactivity) $\Delta-\Delta$.

amide gel electrophoresis in a medium containing dodecylsulfate (fig. 4) [7]. The final cytochrome $\mathrm{aa}_{3}$ preparation, obtained after additional

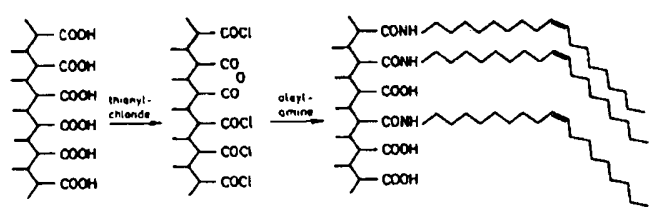

Fig. 2. - Preparation of the oleyl-polymethacrylic acid resin.

Commercial polymethacrylic acid resin (Amberlite CG 50 III, Serva Feinbiochemica, Heidelberg) was refluxed in thionylchloride, the excess thionylchloride was removed, the partially chlorinated, partially anhydrated resin was suspended in dichloromethan and oleylamine and triethylamine were added [6]. The resulting resin contained $3.6 \mathrm{meq} / \mathrm{g}-\mathrm{COOH}, 66,3 \mathrm{p}$. cent $C, 9,6$ p. cent $H$ and 2,2 p. cent $N$.

chromatography on DEAE-cellulose, was found to contain at least six different polypeptides with apparent molecular weights within the range of 8000 to 36000 (fig. 5) $[8,9]$.

BIOCHIMIE, 1973, 55, n 6-7.
In order to attribute the different cytochrome b and cytochrome $\mathrm{aa}_{3}$ polypeptides to either the mitochondrial or the cytoplasmic protein synthe-

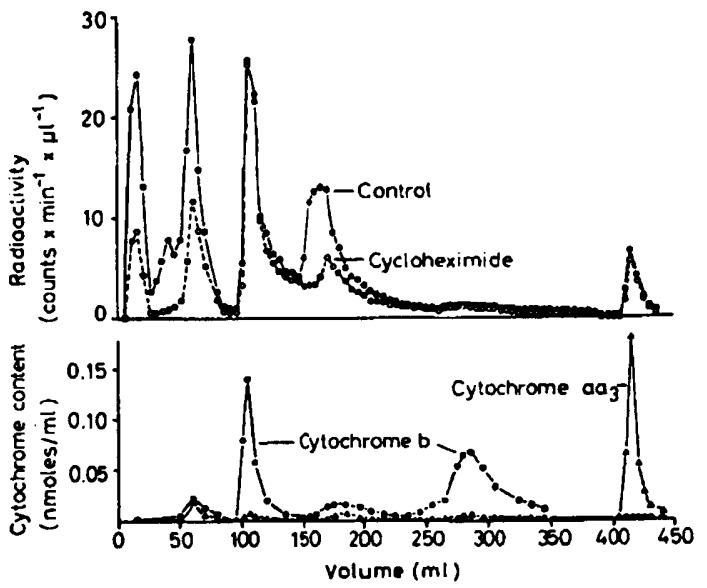

FIG. 3. - Chromatography of mitochondrial membrane proteins on oleyl-polymethacrylic acid resin.

$(14 \mathrm{C})$-leucine was incorporated in the absence and (3H)-leucine in the presence of cycloheximide (see Table 1), - $14 \mathrm{C}$ radioactivity, $\mathrm{O}-\mathrm{O} 3 \mathrm{H}$ radioactivity, $\triangle-\Delta$ cytochrome $\mathrm{aa}_{3}, 0 \longrightarrow 0$ cytochrome b. The chromatographic procedure is described elsewhere [7].

sizing system, the products of each of the two systems were selectively labeled as follows (Table I) : To a culture of exponentially growing

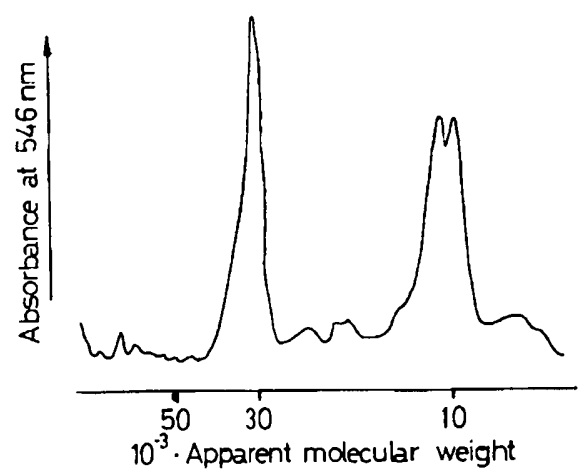

FIG. 4. - Cytochrome $b$ polypeptides separated by gel electrophoresis.

Absorbance' of the coomassie brilliant blue stained protein bands. The molecular weight scale used in the abscissa is calibrated by means of proteins of known molecular weights [7].

Neurospora crassa cells $\left({ }^{14} \mathrm{C}\right)$-leucine $(0.05 \mathrm{mCi} / \mathrm{g}$ protein) was added and the cells were allowed to grow for another three hours. During this 
TABLE.

The effect of cycloheximide and chloramphenicol on incorporation of $\left({ }^{3} \mathrm{H}\right)$-leucine into the proteins of cytoplasm and mitochondrial membrane from Neurospora crassa.

(14C)-leucine was incorporated before the addition of the inhibitors.

\begin{tabular}{|c|c|c|c|c|c|c|}
\hline \multirow{3}{*}{ Addition } & \multicolumn{4}{|c|}{ Specific radioctivity } & \multirow{2}{*}{\multicolumn{2}{|c|}{$\begin{array}{l}\text { Ratio } \\
{ }^{3} \mathrm{H} /{ }^{14} \mathrm{C}\end{array}$}} \\
\hline & \multicolumn{2}{|c|}{${ }^{14} \mathrm{C}$} & \multicolumn{2}{|c|}{${ }^{3} \mathrm{H}$} & & \\
\hline & Cytoplasm & $\begin{array}{c}\text { Mitochoodrial } \\
\text { membrave }\end{array}$ & Cytoplasm & $\begin{array}{c}\text { Mitochondrial } \\
\text { membrane }\end{array}$ & Cytoplasm & $\begin{array}{c}\text { Mitochondrial } \\
\text { membrane }\end{array}$ \\
\hline & \multicolumn{4}{|c|}{ Counts $\times \min ^{-1} \times \mu g$ protein -1} & & \\
\hline 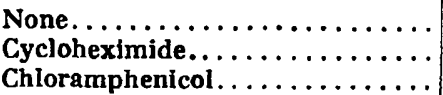 & $\begin{array}{r}86 \\
100 \\
91\end{array}$ & $\begin{array}{l}78 \\
94 \\
86\end{array}$ & $\begin{array}{r}300 \\
4 \\
300\end{array}$ & $\begin{array}{l}262 \\
113 \\
257\end{array}$ & $\begin{array}{l}3.5 \\
0.04 \\
3.3\end{array}$ & $\begin{array}{l}3.4 \\
1.2 \\
3.0\end{array}$ \\
\hline
\end{tabular}

period the total cell protein was labeled by incorporation of $\left({ }^{14} \mathrm{C}\right)$-leucine. Then the culture was divided into three equal portions for separate labeling of proteins synthesized in either mitochondria or cytoplasm, one portion remaining untreated and serving as control. To the second portion cycloheximide $(0.1 \mathrm{mg} / \mathrm{ml})$, an inhibitor of the cytoplasmic protein synthesis, was added and to the third portion chloramphenicol $(4 \mathrm{mg}$ /

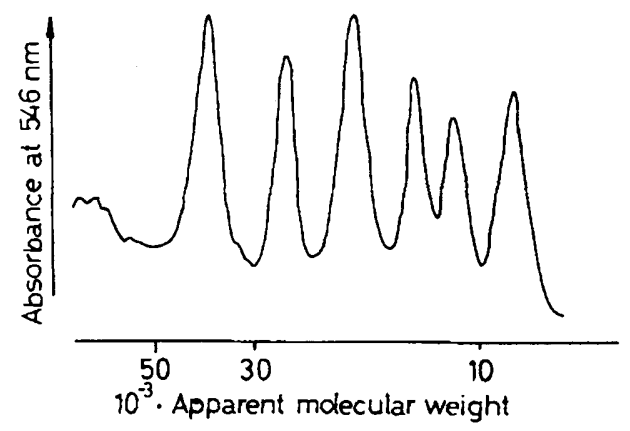

Fig. 5. - Cytochrome aas polypeptides separated by gel electrophoresis.

Absorbance of the coomassie brilliant blue stained protein bands.

$\mathrm{ml}$ ), an inhibitor of the mitochondrial protein synthesis. Two minutes thereafter an equal amount of $\left({ }^{3} \mathrm{H}\right)$-leucine $(0.5 \mathrm{mCi} / \mathrm{g}$ protein) was given to each portion and was incorporated for one hour. Then the three portions were harvested. Cytochrome $b$ and cytochrome $\mathbf{a a}_{3}$ were isolated and separated into polypeptides by gel electrophoresis.

In untreated cells serving as control, $3 \mathrm{H}$ and ${ }^{14} \mathrm{C}$ radioactivity was equally distributed between the electrophoretic fractions of cytochrome b (fig. $6 \mathrm{~A}$ ). This points to an equal rate of protein

BIOCHIMIE, $1973,55, \mathrm{n}^{\circ} 6-7$.

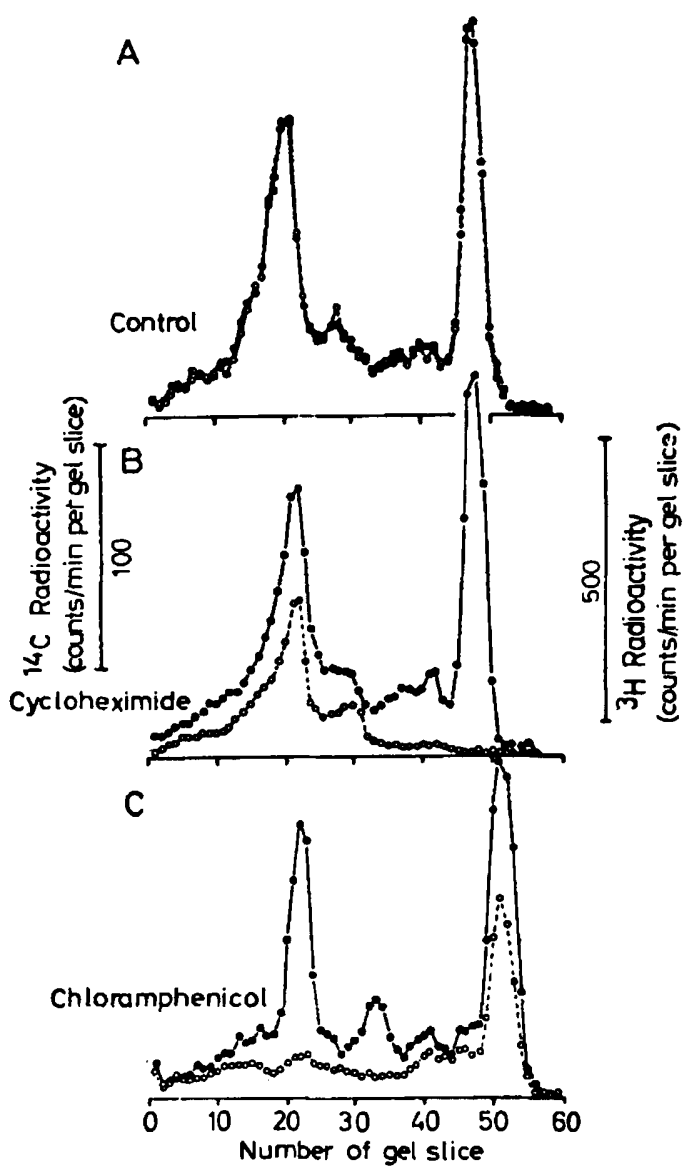

Fig. 6. - Effect of cycloheximide and chloramphenicol on incorporation of $(\mathrm{sH})$-leucine into the cytochrome b polypeptides from Neurospora crassa.

(A) Cytochrome b from untreated cells. (B) Cytochrome $b$ from cycloheximide-treated cells. (C) Cytochrome b from chloramphenicol-treated cells. For measurement of radioactivity the gels were cut into slices. This slicing procedure did not allow a resolution of the two smaller polypeptides. - $14 \mathrm{C}$ radioactivity, $\bigcirc-O 3 \mathrm{H}$ radioactivity ; $(14 \mathrm{C})$-leucine was incorporated before the addition of the inhibitors. 
synthesis during the two labelling periods. In the cells treated with cycloheximide the labeling of the two smaller cytochrome $b$ polypeptides was inhibited (fig. $6 \mathrm{~B}$ ). In the cells treated with chloramphenicol the labeling of the larger cytochrome b polypeptide was inhibited (fig. $6 \mathrm{C}$ ). These results indicate that the two smaller polypeptides are synthesized by the cytoplasmic system, and the larger polypeptide by the mitochondrial system [7].

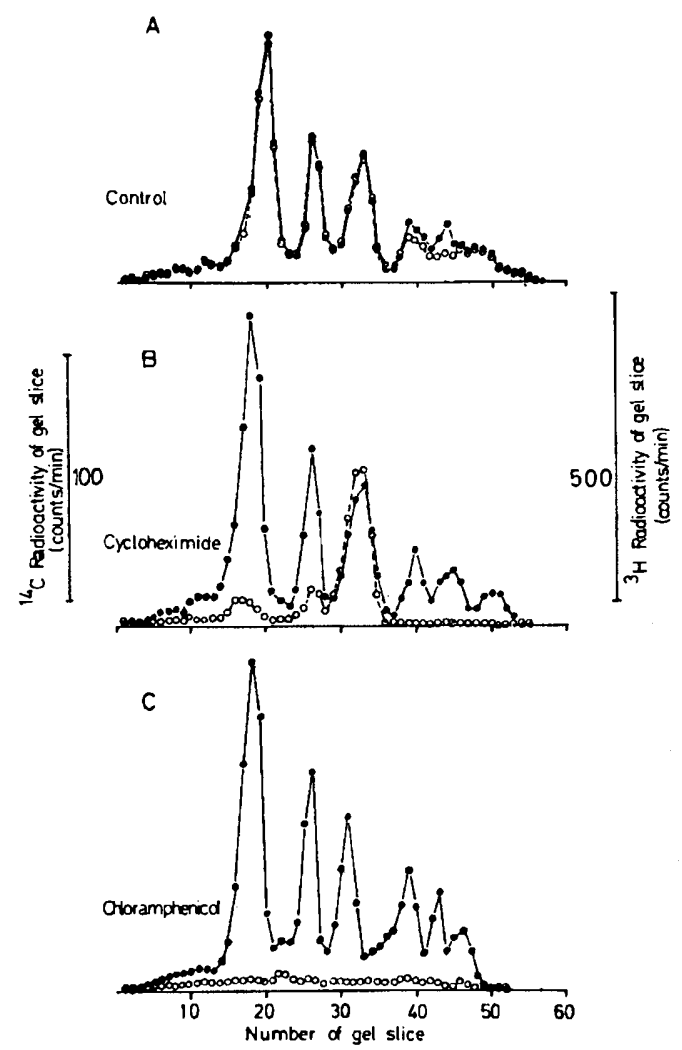

FIG. 7. - Effect of cycloheximide and chloramphenicol on incorporation of $(3 H)$-leucine into the cytochrome aa, polypeptides from Neurospora crassa.

(A) Cytochrome $a_{3}$ from untreated cells. (B) Cytochrome aa ${ }_{8}$ from cycloheximide-treated cells. (C) Cytochrome aa $a_{3}$ from chloramphenicol treated cells. cine was incorporated before the addition of the inhibitors.

In cytochrome $\mathrm{aa}_{3}$ from untreated cells no signiflcant difference in the ${ }^{3} \mathrm{H}$ content of the six bands could be detected (fig. $7 \mathrm{~A}$ ). In cytochrome $\mathrm{aa}_{3}$ from cycloheximide-treated cells only the band at the molecular weight region of 180.00 shows a high label of $3 \mathrm{H}$ radioactiviy (fig. $7 \mathrm{~B}$ ). In cytochrome $\mathrm{aa}_{3}$ from chloramphenicol-treated cells no band at all was labeled with $3 \mathrm{H}$ radioactivity (fig. $7 \mathrm{C}$ ). From these results one only can deduce that the cytochrome $\mathrm{aa}_{3}$ polypeptide with the apparent molecular weight of 18000 is synthesized by the cycloheximide insensitive but chloramphenicol sensitive mitochondrial system

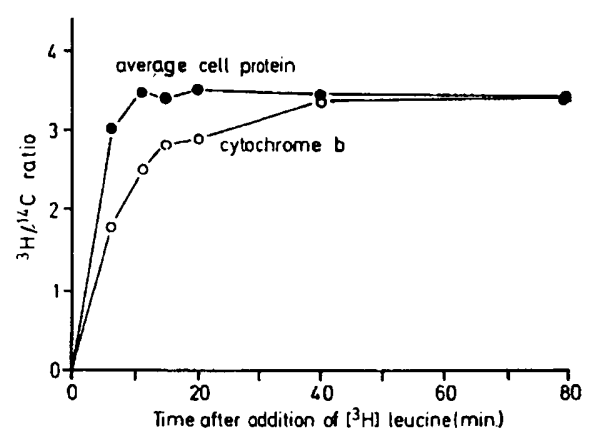

Fig. 8. - Time-course of labeling

of the average cell protein and of cytochrome $b$.

$(3 \mathrm{H})$-leucine was added 200 minutes after the addition of $(14 \mathrm{C})$-leucine.

[8] : only this polypeptide fullfills both criteria, labeling in the presence of cycloheximide and non labeling in the presence of chloramphenicol. For the other cytochrome $\mathbf{a a}_{3}$ polypeptides this complementary effect of cycloheximide and chloramphenicol on incorporation of amino acids does not hold true.

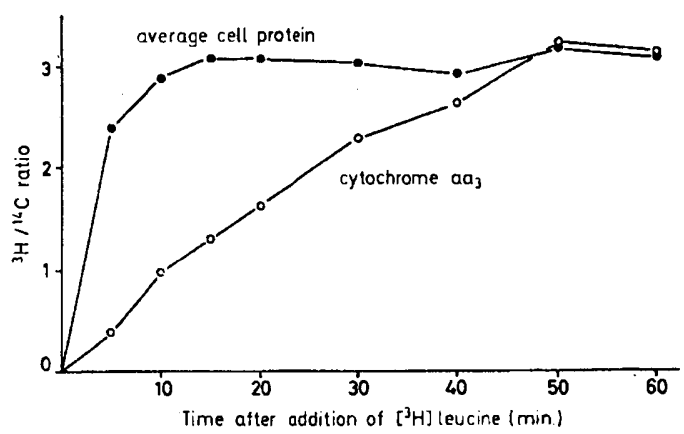

Fig. 9. - Time-course of labeling

of the average cell protein and of cytochrome $a a_{s}$. $(3 \mathrm{H})$-leucine was added 200 minutes after the addition of $(14 \mathrm{C})$-leucine.

However, how is labeling of a single polypeptide in a complex protein possible at all when the synthesis of the other polypeptides present is simultaneously inhibited ? An answer to this question was given by investigating the time course

BIOCHIMIE, $1973,55, \mathrm{n}^{\circ} 6-7$. 
of appearance of radioactivity in these cytochromes [5] : Neurospora crassa cells were first treated with a pulse of $\left({ }^{14} \mathrm{C}\right)$-leucine $(0.05 \mathrm{mCi} / \mathrm{g}$ protein). Most of ${ }^{14} \mathrm{C}$ label would be at its definite position after 200 minutes. At this time $\left({ }^{3} \mathrm{H}\right)$-leucine $(0.4 \mathrm{mCi} / \mathrm{g}$ protein) was added. Thereafter, portions were taken from the culture at short

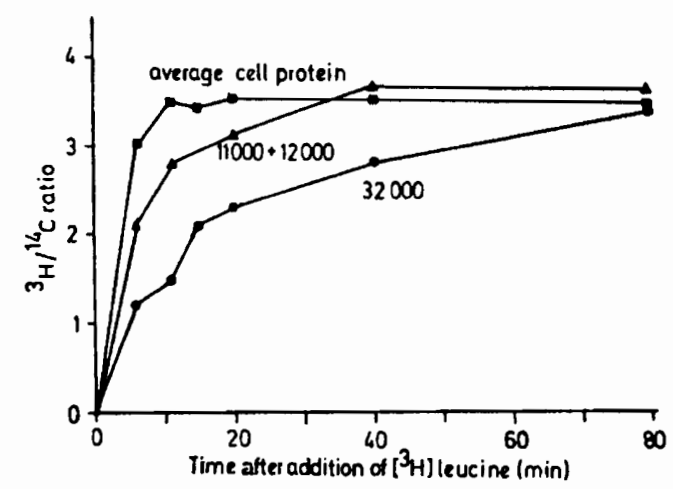

Frg. 10. - Time-course of labeling of the cytochrome b polypeptides.

The numbers indicate the apparent molecular weights of the polypeptides. Labeling conditions as in fig. 8 and 9.

time intervals, immediately deeply frozen and then disrupted for preparation of the cytochromes. In an approximation the ${ }^{3} \mathrm{H} /{ }^{14} \mathrm{C}$ ratio of the proteins corresponds to the relative specific ${ }^{\mathrm{B}} \mathrm{H}$ radioactivity.

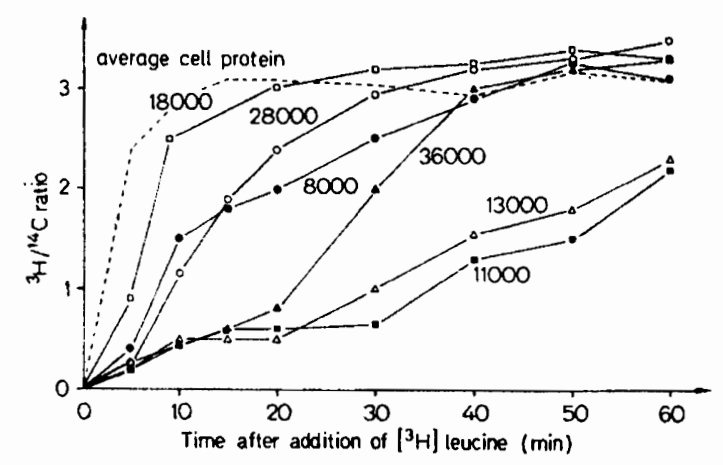

FIG. 11. - Time-course of labeling of the cytochrome aa, polypeptides.

The numbers indicate the apparent molecular weights of the polypeptides. Labeling conditions as in fig. 8 and 9.

In the average cell protein the ${ }^{3} \mathrm{H} /{ }^{14} \mathrm{C}$ ratio shows a rapid increase within the first five minutes and reaches a constant level already after 10 minutes. In contrast, in cytochrome b the $\mathbf{3 H} /$
${ }^{14} \mathrm{C}$ ratio reaches the constant level only after $30-40$ minutes (fig. 8). In cytochrome $a_{3}$ the delay of appearance is even more distinct, the

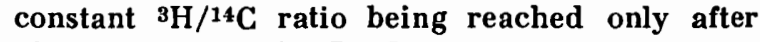
50 minutes (fig. 9). In the single cytochrome b and cytochrome $\mathrm{aa}_{3}$ polypeptides the ${ }^{3} \mathrm{H} /{ }^{14} \mathrm{C}$ ratio follows different time courses (fig. 10 and 11).

It is reasonable to assume an equally high translation rate of all proteins in exponentially growing cells. Thus, the slower labeling rates of

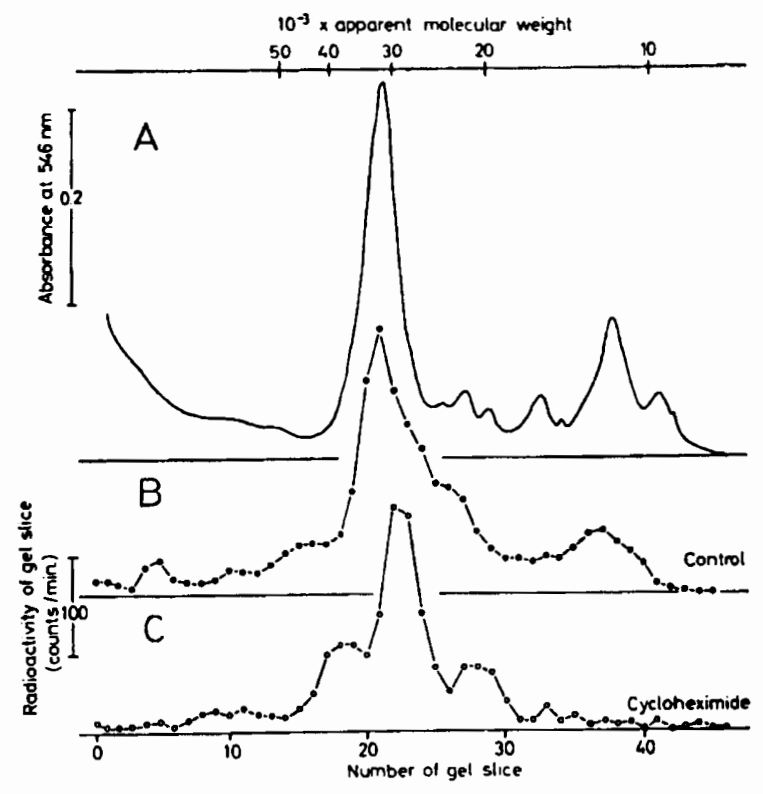

Fig. 12. - Polypeptides of cytochrome $b$ from Locusta migratoria.

(A) Absorbance of the coomassie brilliant blue stained protein bands. (B) Radioactivity incorporated in the absence of cycloheximide $\left(0.1 \mathrm{mCi}\left({ }^{3} \mathrm{H}\right)\right.$-leucine in $20 \mu \mathrm{l}$ saline per locust). (C) Radioactivity incorporated in the presence of cycloheximide $(0.25 \mathrm{mCi}(3 \mathrm{H})$ leucine plus $50 \mu \mathrm{g}$ cycloheximide in $20 \mu \mathrm{l}$ saline per locust).

the cytochrome $\mathrm{b}$ and cytochrome $\mathrm{aa}_{3}$ polypeptides compared to the average cell protein suggest the occurrence of precursor polypeptides. The larger the precursor pool to be passed, the more delayed will radioactivity appear in the final protein. The different time courses of appearance of ${ }^{3} \mathrm{H}$ radioactivity in the single cytochrome $b$ and cytochrome $\mathrm{aa}_{3}$ polypeptides indicate separate pools of precursor polypeptides with different pool sizes $[5,7]$. In the case that only one precursor is involved in the formation of a given polypeptide the balf-life of the precursor can be approximated by the following difference of times needed for half-maximal labeling : 
$t_{1 / 2}$ (precursor) $=t_{1 / 2}$ (end polypeptide) $-t_{1 / 2}$ (average protein) By $t_{1 / 2}$ (average protein) the effect of the cellular pool of free leucine is accounted for. As no protein breakdown and no turnover of cytochromes could be detected in exponentially growing Nellrospora crassa cells the turnover rate of a precursor is equal to the rate of net increase of the end product. The total cell mass doubles in approximately 200 minutes and the total amount of cytochromes doubles in the same time. The ratio of the amount of the precursor to that of the corresponding end product will then be equal to the ratio of the half-life of the precursor to the doubling time of the whole culture [5].

By this means the pool size of the larger cytochrome $b$ polypeptide, the synthesis of which is inhibited by chloramphenicol, was evaluated to be about three times the pool size of the two smaller cytochrome b polypeptides [7]. Consequently, after inhibiting the synthesis of the larger polypeptide by chloramplenicol, the whole cytochrome b protein can still be formed for a limited time until the precursor pool of this polypeptide is exhausted. Thus, it is possible for a newly synthesized ${ }^{\mathrm{H}} \mathrm{H}$ labeled smaller polypeptide to be integrated into the whole protein for a limited time.

The cytochrome $a_{3}$ polypeptide with the apparent molecular weight of 18000 however, shows only a very small delay of labeling compared to the average cell protein, indicating a very small pool size of its precursor polypeptide. This polypeptide was shown to be synthesized by the chloramphenicol sensitive mitochondrial system. Consequently, soon after the addition of chloramphenicol the precursor pool of this polypeptide is exhausted, making a further formation of the whole protein impossible. This fact explains why after the addition of chloramphenicol no cytochrome aa ${ }_{3}$ polypeptide, whether its synthesis is inhibited or not, can be integrated into the whole cytochrome aa $a_{3}$ protein. After washing out the chloramphenicol and further growth of the cells the ${ }^{3} \mathrm{H}$ label of the three smaller cytochrome $\mathrm{aa}_{3}$ polypeptides increases and in addition one band in the molecular weight region of 17000 is revealed, whereas the ${ }^{3} \mathrm{H}$ label of the three larger cytochrome $\mathrm{aa}_{3}$ polypeptides remains nearly unchanged. This indicates that three to four smaller cytochrome $\mathbf{a a}_{3}$ polypeptides are synthesized in the presence of chloramphenicol but not integrated into cytochrome $\mathrm{aa}_{3}$ and it may be looked as a lint of the mitochondrial origin of the three larger cytochrome $\mathbf{a a}_{3}$ polypeptides [9].

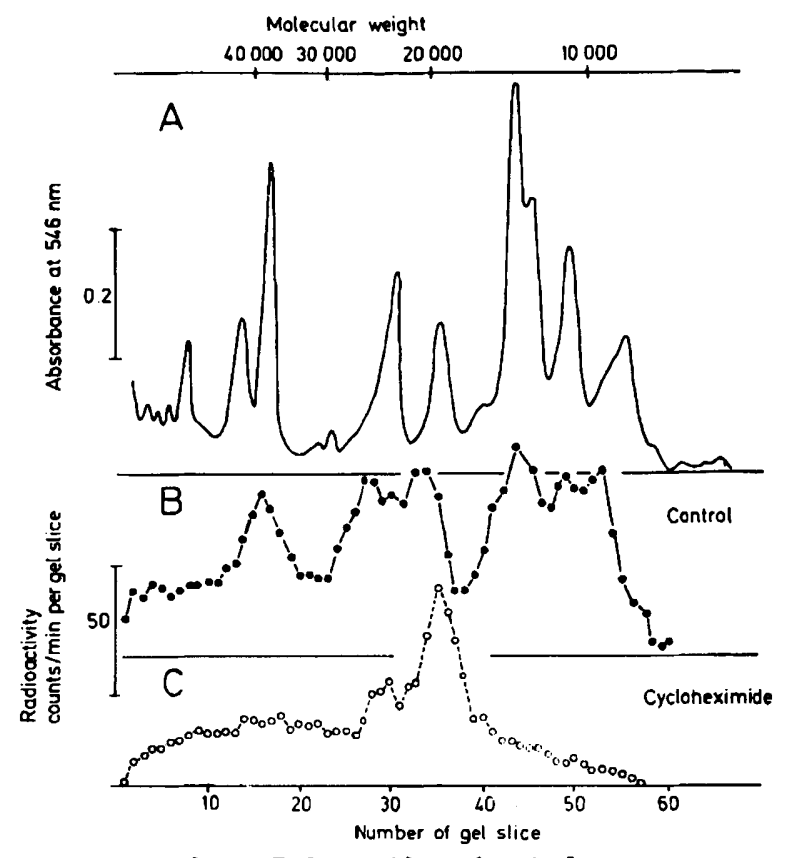

FIG. 13. - Polypeptides of cytochrome $a a_{3}$ from Locusta migratoria.

(A) Absorbance of the coomassie brilliant blue stained protein bands. (B) Radioactivity incorporated in the absence of cycloheximide. (C) Radioactivity incorporated in the presence of cycloheximide. Labeling conditions as in fig. 12 .

Indeed, cycloheximide-resistant labeling of the three larger cytochrome $\mathrm{aa}_{3}$ polypeptides has been reported with yeast [10].

Summarizing, both kinds of polypeptides, from cytoplasmic and from mitochondrial origin, are present in cytochrome $\mathrm{b}$ and cytochrome $\mathrm{aa}_{3}$ of fungi. One out of three cytochrome b polypeptides and one to three out of six to seven cytochrome $\mathrm{aa}_{3}$ polypeptides are mitochondrial translation products.

Now, it is well known that the size of the mitochondrial DNA is considerably smaller in higher animals than in fungi [11]. Hence one may ask, whether or not products of the mitochondrial protein synthesis have been eliminated in the course of cvolution of higher organisms. In order to answer this question, the cycloheximide-resistant incorporation of $\left({ }^{3} \mathrm{H}\right)$-leucine into the cytochrome $b$ and cytochrome $\mathrm{aa}_{3}$ polypeptides from Locusta migratoria was investigated. The flight muscles of this insect proved to be an appropriate tissue. At the imaginal moult it is formed from a precursor muscle within a few days showing a tenfold increase of cell mass and even a fiftyfold increase of mitochondrial mass [12]. 
The electrophoretic pattern of a cytochrome b preparation from locusts revealed two main fractions which may be attributed to polypeptides with apparent molecular weights of 12000 and 32000 . In the presence of cyclohexinide only the 32000 polypeptide incorporated radioactivity (fig. 12) [13]. The electrophoretic pattern of cytoclirone $\mathrm{aa}_{3}$ from locusts revealed seven main fractions. All fractions incorporated $\left({ }^{3} \mathrm{H}\right)$-leucine in the absence of cycloheximide. However, with cycloheximide present, only the fraction attributed to a polypeptide with the apparent molecular weight of 19000 incorporated a significant amount radioactivity (fig. 13) [14].

The good agreement of these results obtained with the insect Locusta migratoria with the results obtained with the fungus Neurospora crassa suggest a universal mitochondrial contribution to the formation of cytochrome $b$ and cytochrome $a a_{3}$.

\section{RÉSUMÉ.}

Une préparation de cytochrome b de mitochondries de Neurospora crassa consiste en trois polypeptides (masses moléculaires apparentes : 10000,11000 et 32000 ), alors qu'une préparation de cytochrome $\mathrm{aa}_{3}$ apparait constituée de six à sept polypeptides (masses moléculaires apparentes : $8000,11000,13000,18000$, 28000 et 36000 ).

L'incorporation sélective d'amino-acides radioactifs, soit par la synthèse protéique mitochondriale quand la synthèse cytoplasmique est bloquée, soit par la synthèse protéique cytoplasmique quand la synthèse mitochondriale est bloquée, indique qu'un polypeptide du cytochrome b (PM. 32 000) et un à trois polypeptides du cytochrome $\mathrm{aa}_{3}$ (PM. 36000, 28000 et $18000)$ sont des produits de traduction mitochondriale, les autres polypeptides cytochromes des $b$ et $a_{a}$ sont des produits de traduction cytoplasmique.

Le retard dans l'apparition de marquage dans les polypeptides cytochromes $b$ et $a a_{3}$, comparativement à l'apparition des protéines cellulaires, après pulsation de leucine $3 \mathrm{H}$, révèle que ces polypeptides proviennent de lots de précurseurs polypeptidiques séparés. La taille de ces lots s'échelonne de 2 p. 100 à 25 p. 100 de la quantité de polypeptides présents dans les cytochromes.

Le polypeptide 32000 du cytochrome b et au moins Je polypeptide 18000 du cytochrome $a_{3}$ sont des produits de traduction mitochondriale aussi bien chez le champignon Neurospora crassa que chez l'insecte Locusta migratoria. Ainsi, en dépit du fait que la taille du DNA mitochondrial et des ribosomes mitochondriaux est réduite chez les insectes, les produits ont conservé leurs caractéristiques.

\section{REFERENCES}

1. M t.hell, M. B. Mitchell, H. K'. Tissières, A. (1953) Proc. Nat. A cad. Sci. U.S.A., 39, 606-613.

2. Ephrussi, B. Slonimski, P. P. (1955) Nature, 176, 1207-1208.

3. Clark-Walker, G. D. \& Linnane, A. W. (1967) J. Cell. Biol., 34, 1-14.

4. Rouslin, W. \&chatz, G. (1969) Biochem. Biophys. Res Commun., 37, 1002-1007.

5. Schwab, A. J., Sebald, W. \& Weiss, H. (1972) Eur. J. Biochem., 30, 511-516.

6. Weiss, H. \& Bücher, Th. (1970) Eur. J. Biochem., $17,561-567$

7. Weiss, H. (1972) Eur. J. Biochem., 30, 469-478.

8. Weiss, H, Sebald, W. Bücher, Th. (1971) Eur. J. Biochem., 22, 19-26.

9. Sebald, W., Weiss, H. \& Jackl, G. (1972) Eur. J. Biochem., 30, 413-417.

10. Mason, T. L. and Schatz, G. (1973) J. Biol. Chem., 248, $1355-1360$

11. Borst, P. (1972) Ann. Rev. Biochem. 41, 333-376.

12. Brosemer, R. W., Vogell, W. * Bücher, Th. (1963) Biochem. $Z$., 338, 854-910.

13. Lorenz, B., Kleinow, W. \&eiss, H., in preparation.

14. Weiss, H., Lorenz, B. \& Kleinow, W. (1972) FEBS Letters, 25, 49-51. 